\title{
Carbonado from Yakutian diamond deposits (Russia): microinclusions, impurities, and paramagnetic centers
}

Titkov, S.V., Gorshkov, A.I., Vinokurov, S.F., Bershov, L.V., Solodov, D.I., and Sivtsov,A.V.

Institute of Geology of Ore Deposits, Petrography, Mineralogy and Geochemistry, Russian Academy of Sciences, Staromonetny per. 35, Moscow 109017, Russia

At present the genesis of cryptocrystalline varieties of natural diamonds, carbonado, appears to be a problem under discussion because most carbonado samples were found in placer deposits with unknown sources. In particular, the hypothesis of non-kimberlite origin of carbonado has been proposed (Kaminsky, 1995).

In this work three carbonado samples from Yakutian diamond deposits (Russia) with unknown geological localities and complex polycrystalline aggregate from the kimberlite pipe "Udachnaya" from the same area have been studied. Microinclusions were revealed by Analitical Transmission Electron Microscopy (ATEM), impurities were detected by Instrumental Neutron Activation Analysis (INAA) and paramagnetic centers were observed by Electron Paramagnetic Resonance (EPR).

The carbonado samples N1-3 under investigation, being 1.5-2 carat in weight, were dark grey on broken surface and black on natural undisturbed surface, representing sings of corrosion effect. The aggregates were porous (the most pores were observed in sample N2). Sample N4 from the "Udachnaya" pipe consisted of grey micrograin mass structurally similar to the carbonado inside and single diamond crystals above $1 \mathrm{~mm}$ in size on the surface (Gorshkov et al.).

Methods. Microinclusions were studied with the Electron Microscope JEM-100C (JEOL) equipped with the energy dispersion spectrometer Kevex-5100. For study suspension specimens were prepared. Energy-dispersion spectra characterizing chemical composition, and electron diffraction patterns revealing parameters of the structure, were obtained from micron-size particles.

INAA was performed in the laboratory of the IGEM RAS according to a standart procedure (analyst A.L.Kerzin).

The EPR-spectra were recorded with Varian E-115 and RE-1306 spectrometers in X-band (about $\sim 9 \mathrm{GHz}$ ) with modulation frequences of 100 and $25 \mathrm{GHz}$.

Results. Using ATEM in carbonado sample N1, microinclusions of anatase, rutile, muscovite, zircon, and florensite were revealed. In sample $\mathrm{N} 2$, rutile, sphalerite, native $\mathrm{Cr}, \mathrm{Fe}$, kaolinite, and 
goethite were found. In sample N3, respectively, rutile, zircon-xenotime solid solutions and intergrowths, native $\mathrm{Cr}, \mathrm{Fe}, \mathrm{Ni}$, pentlandite, and florensite were detected.

In micrograin masses of the sample $\mathrm{N} 4$, the same inclusions of native metals $-\mathrm{Fe}, \mathrm{Cr}, \mathrm{Ni}, \mathrm{Cu}, \mathrm{Tl}$, alloy of Fe-Ni and Fe-Cr, sulphids - sphalerite, wustite, and pyrite were disclosed. Moreover, there were found inclusions of $\mathrm{Cr}$-shpinel, magnetite, and $\mathrm{TlCl}$.

According to INAA data, sample N3 stood out for the highest Rare Earth Elements (REE) ( $\sum \mathrm{Ln}=$ $361 \mathrm{ppm})$ and relatively low metals contents ( $\mathrm{Ag}, \mathrm{Ba}, \mathrm{Zr}, \mathrm{Cr}$ ). On the contrary, in sample N2 relatively low $\operatorname{REE}(\Sigma \mathrm{Ln}=10.5 \mathrm{ppm})$ and raised metals concentrations were fixed. Sample N1 had the intermediate position.

In the polycrystalline diamond aggregate, high $\mathrm{Cr}$ and $\mathrm{Fe}$, raised $\mathrm{Zn}$ and $\mathrm{Tl}$, and lower lanthanoids contents $(\Sigma \mathrm{Ln}=7 \mathrm{ppm})$ were observed.

Note should be taken that high REE contents were fixed in the samples where impurities of REEconcentrating minerals, namely, florensite, zircon, and zircon-xenotime solid solutions, were found. The distribution curves for the main REE were obtained by a standart method, using the corresponding value for chondrite. The samples of carbonado and polycrystalline diamond aggregates were characterised by the negative type of REE distribution curves with the obvious predominant of light lanthanoids, which is typical for kimberlites, in particular for kimberlites from the "Udachnaya" pipe (Fig. 1). Furthermore, the REE distribution in samples N2 and N4 was corresponded to REE the distribution in darkgrey coat of zonal diamond from kimberlites (Bibby, 1979).

Using the EPR-spectroscopy, the centers P1 (single nitrogen atoms), exchange coupled nitrogen atoms centers, the centers W15 (vacancy with nitrogen atom) (Mineeva et al.), and the signals in spectrum area with g 4 were detected. The EPR-spectra of the P1 centers were typical for spectra of polycrystalline aggregates, which corresponded to the carbonado structure. The concentration of the $\mathrm{Pl}$ centers reached the value $\mathrm{n} \times 10^{19} \mathrm{spin} / \mathrm{g}$.

Discussion. Among the microinclusions fixed in carbonado, florensite, kaolinite and goethite have obviously epigenetic origin, as their location in carbonado pores shows.

Florensite perhaps displays epigenetic hydrothermal-metasomatic treatment which carbonado may undergo, in particular, in fluid rich kimberlite magma.

Most other microinclusions found in the carbonado samples, seems to be singenetic and were fixed preveously in diamond crystals from kimberlites (Meyer, 1987), which shows the genetic similiarity of single diamond crystals and polycrystalline aggregates. 
Native metals findings in natural carbonado samples have revealed the reduction environment where carbonado were crystallized. If native $\mathrm{Ni}$ is able to crystallize at a relatively high oxygen fugacity, then for native $\mathrm{Cr}$ and $\mathrm{Fe}$ formation the reduction environment corresponding to JW (Fe$\mathrm{FeO}$ ) buffer is necessary.

High concentration of the P1 paramagnetic centers implies that carbonado were not subjected to the post-growth annealing under high thermodynamic parameters (on the contrary to the most diamond crystals).

Association of singenetic inclusions and REE distribution patterns in the carbonado being studied may indicate their possible kimberlite origin. This is corroborated by finding of the complex polycrystalline aggregate in the kimberlite pipe "Udachnaya", with its inner part being similar with carbonado.

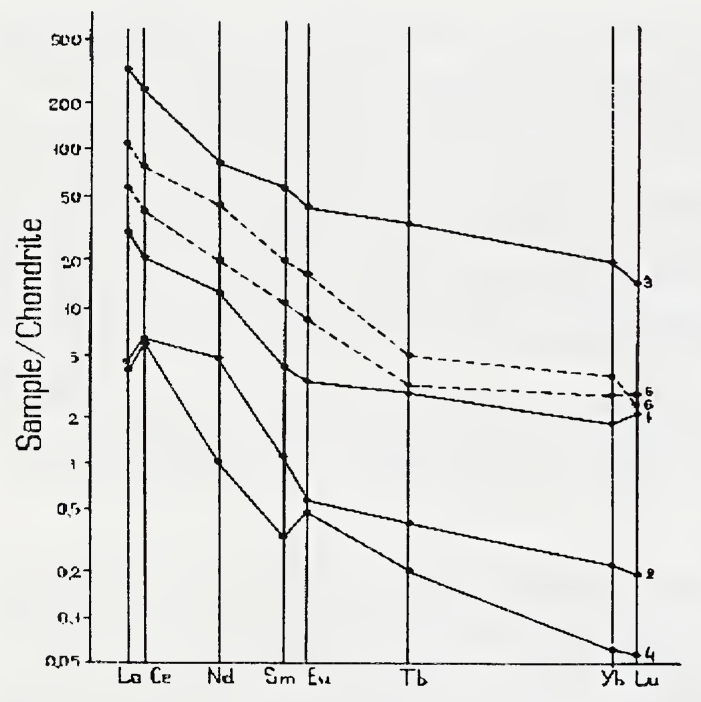

Fig. 1. REE distribution patterns:

(1) carbonados sample $\mathrm{Nl}$; (2) carbonados sample N2; (3) carbonados sample N3; (4) polycrystalline aggregates from kimberlite pipe "Udachnaya" sample N4; (5) kimberlite from "Udachnaya" pipe; (6) kimberlite from "Udachnaya" pipe;

\section{References.}

Bibby, D.M., 1979, Zonal distribution of impurities in diamond: Geochim. Et. Cosmochim. Acta, 43, p. 415-423.

Gorshkov, A.I., Vinokurov, S.F., Solodov, D.I., Bershov, L.V., Mokhov, A.V., Solodova, J.P., and Sivtsov, A.V. Polycrystalline aggregate from the "Udachnaya" pipe (Yakutia): mineralgeochemical and genetic featuries: Lithology and Mineral Resources (in Russian, in press).

Kaminsky, F.V., 1995, Carbonado and yakutite: properties and possible genesis: in Proc. Fifth Intern. Kimberlite Conf., V. 2, CPRM, Rio de Janeiro, p. 136-143.

Mineeva, R.M., Speranskiy, A.V., Egorov, B.L., Bershov, L.V., and Chukichev, M.V., Defects in carbonado: the stable paramagnetic center which is analogue of the radiation center W15 in diamond: Doklady RAN (in Russian, in press). 